\title{
Factors associated to Caesarean delivery in public and private health care systems
}

\author{
Fatores associados ao parto cesárea nos sistemas público e privado de atenção à saúde \\ Factores asociados con el parto cesárea en el sistema público y privado de atención sanitaria
}

Rosana Rosseto de Oliveira ${ }^{1}$, Emiliana Cristina Melo² ${ }^{2}$ Elisiane Soares Novaes ${ }^{1}$, Patrícia Louise Rodrigues Varela Ferracioli ${ }^{1}$, Thais Aidar de Freitas Mathias ${ }^{3}$

Como citar este artigo:

Oliveira RR, Melo EC, Novaes ES, Ferracioli PLRV, Mathias TAF. Factors associated to caesarean delivery in public and private health care systems. Rev Esc Enferm USP. 2016;50(5):733-740. DOI: http://dx.doi.org/10.1590/S0080-623420160000600004

${ }^{1}$ Universidade Estadual de Maringá

Programa de Pós-Graduação em Enfermagem, Maringá, PR, Brazil.

${ }^{2}$ Universidade Estadual do Norte do Paraná, Campus Luiz Meneghel, Bandeirantes, PR, Brazil.

${ }^{3}$ Universidade Estadual de Maringá, Departamento de Enfermagem, Maringá, PR, Brazil.
Corresponding author: Elisiane Soares Novaes Universidade Estadual de Maringá

Av. Colombo, 5.790 - Bloco 002, sala 001 Campus Universitário.

CEP 87020-900 - Maringá, PR, Brazil elisianenovaes@hotmail.com

\begin{abstract}
Objective: Identifying factors associated to Caesarean sections among the residents of Maringá-PR, according to the financing source for delivery. Methods: A crosssectional study with data from 920 postpartum women interviewed between October 2013 and February 2014. Association analysis was performed by logistic regression. Results: Caesarean section rates were $55.5 \%$ in the Unified Healthcare System (SUS) and $93.8 \%$ in the private system. Factors associated with Caesarean section in the SUS were: previous Caesarean section $(\mathrm{OR}=8.9 ; \mathrm{CI}=4.6-16.9)$, desire for Caesarean section early in pregnancy $(\mathrm{OR}=2.0 ; \mathrm{CI}=1.1-3.6)$, pregestational overweight/obesity $(\mathrm{OR}=1.8$; $\mathrm{CI}=1.1-2.8)$, and per capita family income higher than one minimum wage $(\mathrm{OR}=2.1$; $\mathrm{CI}=1.3-3.4)$. In the private system, desire for Caesarean section early in pregnancy $(\mathrm{OR}=25.3)$ and a previous Caesarean section $(\mathrm{OR}=11.3)$ were strongly associated to its performance. Conclusion: It is necessary to properly orientate all pregnant women who desire a Caesarean delivery, from both the SUS and the private system, about the inherent risks of the surgical procedure without indication. In the public health sector, guidelines should be focused on pregnant women with previous Caesarean delivery, with a per capita income higher than one minimum wage and those who are overweight or obese, as these women are more likely to have a Caesarean section.
\end{abstract}

\section{DESCRIPTORS}

Cesarean Section; Risk Factors; Maternal and Child Health; Maternal-Child Nursing; Healthcare Financing. 


\section{INTRODUCTION}

According to the World Health Organization (WHO), there is no reason to justify Caesarean birth rates being higher than $15 \%{ }^{(1)}$. However, the Caesarean section has presented an overall increasing trend, leading to an increase in health service costs and risks of maternal and perinatal morbidity and mortality, with no impacts on reducing perinatal mortality rates ${ }^{(2)}$.

There are differences in Caesarean section rates among different countries and being related to socioeconomic conditions. The rates are higher in more developed regions (27.2\%), in contrast to those observed in extremely underdeveloped regions $(6.0 \%)^{(2)}$. Ecological studies indicate that the rates also differ between regions within the same country, such as in Brazil, which is considered one of the countries with the highest incidence of Caesarean sections in the world and has an upward trend ${ }^{(3-4)}$. The difference encountered is due to multiple and complex determinants, such as obstetric characteristics of women, availability of technological and human resources, and, above all, clinical management protocols used in each location ${ }^{(5)}$. Considering data from the Live Birth Information System (Sistema de Informações sobre Nascidos Vivos - SINASC) in 2013, the North and Northeast regions had rates of $44.5 \%$ and $48.4 \%$, respectively, while caesarean delivery rates were $61.4 \%, 60.6 \%$ and $61.7 \%$ in the Midwest, Southeast and South regions of the country, respectively ${ }^{(6)}$.

For the state of Paraná, the rates are even higher. In 2013, $63.5 \%$ of deliveries were Caesarean sections, and in Maringa (a medium-sized municipality of Paraná), an alarming rate of $79.8 \%$ was recorded in the same period ${ }^{(6)}$. In $2012,56.6 \%$ of births carried out in the Unified Healthcare System (SUS) in Maringa were Caesarean sections; and in the private system, the Caesarean section delivery rate was $97.7 \% \%^{(7)}$, highlighting the discrepancy between what is proposed by WHO and the current situation of surgical deliveries in this municipality, as well as the difference between the accessible care models.

The high surgical birth rates are questioned and criticized by the academic community in the field of obstetrics due to their association with undesirable events for the mother and child, such as the birth of preterm low birth weight infants with respiratory and neurological disorders, and also the high incidence of puerperal maternal infections ${ }^{(8-9)}$.

In this context, the aim of this study was to identify factors associated with Caesarean section in residents of the Maringa-PR municipality, according to the funding source for delivery. The results can help to improve the understanding of this event and trigger actions aimed at reducing its occurrence in the municipality of Maringa, Parana, Brazil, in addition to other cities and regions with similar characteristics.

\section{METHOD}

An observational, cross-sectional analytical study based on data from a survey studying preterm birth and associated factors in Maringá-PR. The data was collected from puerperal women residing in the municipality whose baby was born alive. Maringa has about 400,000 inhabitants (98.2\% residing in urban areas) and a Human Development Index
(HDI) of $0.84^{(10)}$. In the year 2013, there were 4.925 live births to mothers residing in this municipality ${ }^{(6)}$. The sample for the present study represents $18.7 \%$ of such births.

The sample of 920 live birth deliveries was calculated by the following parameters: $78 \%$ of Caesarean section births by mothers residing in the municipality in $2012^{(6)}$, using a $95 \%$ confidence interval, sampling error of $2.5 \%$, with an added $10 \%$ for possible losses. The sample was proportionally stratified among five hospitals in the city; two of the SUS system and three being private.

The main source of data was interviews with the hospitalized mother due to delivery, complemented by an audit of the mother's hospital records and prenatal booklet. A structured questionnaire made electronically on the Google Docs application and previously tested by the researchers was used. Data collection occurred between October 2013 and February 2014 in the municipality of Maringa, through an active daily search in the two SUS hospitals offering delivery service, and three hospitals that only offered deliveries through the private system. The mothers were approached at their maternity ward accommodation while still in the first 48 hours after delivery. Data collection was performed by three previously trained post-graduate nursing students and one hired nurse. The mothers were interviewed and their data were collected consecutively until reaching the sample number for each hospital. Data were checked daily during the collection period and corrected when necessary by returning to the medical records or by telephone contact to the women.

For the association of Caesarean section with maternal characteristics, the following independent socioeconomic and demographic variables of puerperal woman were considered: age ( $\leq 19,20-34$ or $\geq 35)$; education level $(<8$ or $\geq 8$ years of studying); race/color (white or other); marital status (with or without a partner); family income per capita ( $<1$ or $\geq 1$ minimum wages).

Pregestational, gestational and reproductive history characteristics considered were: gestational age at the start of prenatal care ( $<16$ or $\geq 16$ weeks); number of prenatal consultations ( $<7$ or $\geq 7$ appointments); participation in pregnant groups (yes or no); number of previous pregnancies (primiparous, none, or multiparous: $\geq 1$ ); history of obstetrical risk (history of stillbirth, neonatal mortality, previous child with low birth weight, previous child preterm, previous child who died in the first year of life) (yes or no); body mass index (BMI) before pregnancy $<18.5 \mathrm{~kg} / \mathrm{m}^{2}$ (underweight); 18.5 to $24 \mathrm{~kg} / \mathrm{m}^{2}$ (normal); or $\geq 25 \mathrm{~kg} / \mathrm{m}^{2}$ (overweight/obesity); previous caesarean section for multiparous woman (none or $\geq 1$ ).

Other maternal conditions during pregnancy were also considered: unplanned pregnancy (yes or no); mother's reaction to pregnancy (negative or concern, positive); labor in orthostatic position (standing: yes or no); practice of physical activity during pregnancy (yes, if at least three times a week or not); desired type of delivery in early pregnancy (Caesarean section or vaginal).

Finally, complications during pregnancy: hypertension (yes or no); diabetes (yes or no); urinary tract infection (UTI) (yes or no); bleeding (yes or no); placental abruption (yes or no); hospitalization (yes or no); depression (yes or no). 
Per capita income was calculated by summing the monthly household income and dividing it by the number of household members. When the monthly income was not mentioned by the mother in the number of minimum wages, the mentioned number was divided by the value of the minimum wage at the time ( $\mathrm{R} \$$ 678.00). Presence of depression during pregnancy with a medical diagnosis and specific therapy was asked about in the interview.

The logistic regression model (stepwise forward, using the SPSS software, version 20.1) was used with a confidence interval (CI) of $95 \%$. Only variables with $p$-value $\leq 0.20$ in the univariate analysis were presented in the results and included in the logistic regression analysis. Only variables with $p$-value < 0.05 remained in the final model after controlling for statistical adjustment variables. The categories chosen as reference were those of lower risk for caesarean delivery, considering relevant literature. Two separate regression logistic analyzes were carried out; one for deliveries funded by the Unified Healthcare System (SUS), in which the expenses are paid by the State, and another for the private system, in which the expenses are paid to the health institution by health insurance companies/ plans, or directly by the client. The project was approved by the Ethics Committee of the State University of Maringa-PR (No. 412.422/2013), and met all the ethical principles of the Declaration of Helsinki. All ethical precautions were taken and postpartum women who agreed to participate signed the Clear and Informed Consent Form (CICF).

\section{RESULTS}

Of the 920 postpartum women interviewed, 485 underwent delivery using the public health system and 435 using the private system. Regarding the type of delivery, the highest proportion of Caesarean section was observed among mothers who went through the private system $(93.8 \%=408)$, however, the proportion of Caesarean section through SUS was also high $(55.5 \%=269)$.

In the first stage of the association analyzes (OR) for selecting the variables that were included in the logistic regression analysis $(p<0.20)$, it is observed that no maternal socioeconomic and demographic characteristics were associated with Caesarean section $(p<0.05)$. BMI classified as "overweight or obese" $(p<0.001)$ and the occurrence of previous Caesarean section $(p<0.006)(\mathrm{OR}=2.24 ; \mathrm{CI}=1.51-3.33$ and $\mathrm{OR}=16.99$; $\mathrm{CI}=2.23-129.40$, respectively) increase the chances of Caesarean section for women who underwent delivery through the SUS. For those who had their delivery financed by the private system, it can be observed that the performance of less than seven prenatal consultations $(p=0.012)$ and pre-pregnancy BMI classified as "underweight" $(p=0.048)$ are also factors associated with Caesarean section $(\mathrm{OR}=0.22 ; \mathrm{CI}=0.07-0.71$ and $\mathrm{OR}=0.30 ; \mathrm{CI}=0.09-0.99$, respectively), representing a possible protection factor (Table 1).

Table 1 - Caesarean section birth rates, according to socioeconomic, demographic, pregestational and pregnancy characteristics Maringa, PR, Brazil, 2014.

\begin{tabular}{|c|c|c|c|c|c|c|c|c|c|c|}
\hline \multirow{3}{*}{ Variables } & \multicolumn{5}{|c|}{$\begin{array}{c}\text { SUS } \\
\text { n (485) }\end{array}$} & \multicolumn{5}{|c|}{$\begin{array}{c}\text { Private system } \\
\text { n (435) }\end{array}$} \\
\hline & \multirow{2}{*}{$\begin{array}{c}\text { C-section } \\
55.5 \%\end{array}$} & \multicolumn{4}{|l|}{ Vaginal } & \multirow{2}{*}{$\begin{array}{c}\text { C-section } \\
93.8 \%\end{array}$} & \multicolumn{4}{|l|}{ Vaginal } \\
\hline & & $44.5 \%$ & OR & $\mathrm{Cl}$ & $p$ & & $6.2 \%$ & OR & $\mathrm{Cl}$ & $p$ \\
\hline \multicolumn{11}{|l|}{ Age } \\
\hline$\leq 19$ & 44.2 & 55.8 & 0.62 & $0.37-1.01$ & 0.057 & 87.5 & 12.5 & 0.45 & $0.05-3.18$ & 0.463 \\
\hline $20-34$ & 56.2 & 43.8 & - & 1 & & 94.0 & 6.0 & - & 1 & \\
\hline$\geq 35$ & 66.1 & 33.9 & 1.52 & $0.85-2.72$ & 0.155 & 93.6 & 6.4 & 0.93 & $0.34-2.56$ & 0.896 \\
\hline \multicolumn{11}{|l|}{ Education level } \\
\hline$<8$ years & 54.8 & 45.2 & - & 1 & & 77.8 & 22.2 & - & 1 & \\
\hline$\geq 8$ years & 55.6 & 44.4 & 1.03 & $0.60-1.76$ & 0.916 & 94.1 & 5.9 & 4.58 & $0.90-23.22$ & 0.066 \\
\hline \multicolumn{11}{|c|}{ Family income per capita* } \\
\hline$<1$ minimal wage & 52.5 & 47.6 & - & 1 & & 96.6 & 3.4 & - & 1 & \\
\hline$\geq 1$ minimal wage & 59.1 & 40.9 & 1.31 & $0.91-1.87$ & 0.143 & 93.4 & 6.7 & 0.50 & $0.11-2.14$ & 0.344 \\
\hline \multicolumn{11}{|c|}{ GA at start of prenatal care ${ }^{* *}$} \\
\hline$<16$ & 53.2 & 46.8 & - & 1 & & 94.1 & 5.9 & - & 1 & \\
\hline$\geq 16$ & 65.4 & 34.6 & 1.66 & $1.00-2.75$ & 0.050 & 77.8 & 22.2 & 0.22 & $0.04-1.11$ & 0.067 \\
\hline \multicolumn{11}{|c|}{ Number of prenatal consultations } \\
\hline$<7$ & 54.2 & 45.8 & 0.93 & $0.62-1.41$ & 0.742 & 79.0 & 21.1 & 0.22 & $0.07-0.71$ & 0.012 \\
\hline$\geq 7$ & 55.9 & 44.1 & - & 1 & & 94.5 & 5.5 & - & 1 & \\
\hline \multicolumn{11}{|c|}{ History of obstetrical risk ${ }^{* * *}$} \\
\hline Yes & 62.6 & 37.4 & 1.47 & $0.96-2.26$ & 0.078 & 93.3 & 6.7 & 0.89 & $0.36-2.17$ & 0.800 \\
\hline No & 53.2 & 46.8 & - & 1 & & 94.0 & 6.0 & - & 1 & \\
\hline
\end{tabular}




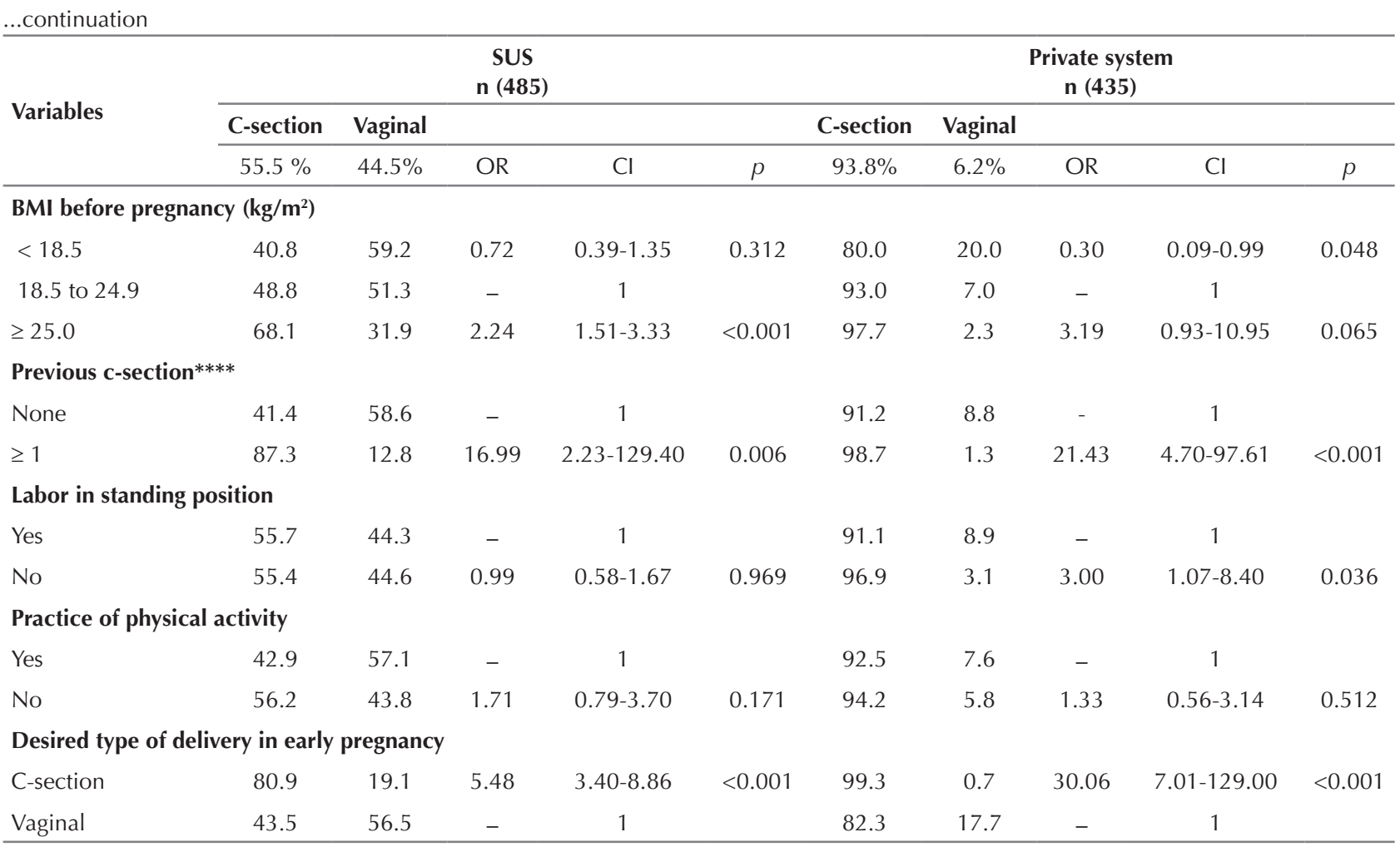

* Current minimum wage in October 2013 (R\$ 678.00).

**GA: gestational age in complete weeks.

*** Having had at least one abortion and/or a previous stillbirth and/or a previous LBW child and/or a previous premature child and/or a child who died in the first year of life.

***: Only multiparous women were considered for this variable.

Of all the maternal conditions during pregnancy, desiring this type of delivery from the beginning of pregnancy $(p<0.001)$ was associated with Caesarean delivery, both for women who underwent delivery through the SUS $(\mathrm{OR}=5.48$; $\mathrm{CI}=3.40-8.86)$, and for those who underwent delivery through the private system $(\mathrm{OR}=30.06$; $\mathrm{CI}=7.01-129.00)$. In the private system, standing labor was associated with the performance of
Caesarean section (OR=3.00, CI=1.07-8.40) (Table 1).

In the SUS, it can also be noticed that maternal complications were associated to Caesarean sections. The presence of hypertension $(\mathrm{OR}=2.10, \mathrm{CI}=1.31-3.37)$, diabetes $(\mathrm{OR}=4.32$; $\mathrm{CI}=1.63-11.50)$ and depression during pregnancy $(\mathrm{OR}=403$; $\mathrm{CI}=1.35-12.02)$ increase the chances of Caesarean section in the public health care system (Table 2).

Table 2 - Caesarean section rates, according to maternal complications during pregnancy - Maringa, PR, Brazil, 2014.

\begin{tabular}{|c|c|c|c|c|c|c|c|c|c|c|}
\hline \multirow{3}{*}{ Variables } & \multicolumn{5}{|c|}{$\begin{array}{c}\text { SUS } \\
\mathrm{n}(\mathbf{4 8 5})\end{array}$} & \multicolumn{5}{|c|}{$\begin{array}{c}\text { Private system } \\
\text { n (435) }\end{array}$} \\
\hline & C-section & Vaginal & & & & C-section & Vaginal & & & \\
\hline & $\%$ & $\%$ & OR & $\mathrm{Cl}$ & $\mathbf{p}$ & $\%$ & $\%$ & OR & $\mathrm{Cl}$ & $p$ \\
\hline \multicolumn{11}{|c|}{ Hypertension } \\
\hline Yes & 69.4 & 30.6 & 2.10 & $1.31-3.37$ & 0.002 & 95.4 & 4.6 & 1.43 & $0.42-4.91$ & 0.566 \\
\hline No & 51.9 & 48.1 & - & 1 & & 93.5 & 6.5 & - & 1 & \\
\hline \multicolumn{11}{|l|}{ Diabetes } \\
\hline Yes & 83.3 & 16.7 & 4.32 & $1.63-11.50$ & 0.003 & 97.7 & 2.3 & 2.98 & $0.39-22.55$ & 0.289 \\
\hline No & 53.6 & 46.4 & - & 1 & & 93.4 & 6.6 & - & 1 & \\
\hline \multicolumn{11}{|c|}{ Hospitalization } \\
\hline Yes & 59.5 & 40.5 & 1.29 & $0.88-1.88$ & 0.191 & 91.4 & 8.6 & 0.58 & $0.26-1.30$ & 0.187 \\
\hline No & 53.3 & 46.7 & - & 1 & & 94.8 & 5.2 & - & 1 & \\
\hline \multicolumn{11}{|l|}{ Depression } \\
\hline Yes & 82.6 & 17.4 & 4.03 & $1.35-12.02$ & 0.013 & 92.9 & 7.1 & 0.85 & $0.11-6.80$ & 0.883 \\
\hline No & 54.1 & 45.9 & - & 1 & & 93.8 & 6.2 & - & 1 & \\
\hline
\end{tabular}


Logistic regression analysis highlighted some factors that may be associated, in varying degrees, with the occurrence of Caesarean section in the SUS: family income per capita lower than one minimum wage $(\mathrm{OR}=2.03$; $\mathrm{CI}=1.10-3,77)$; occurrence of previous caesarean section delivery $(\mathrm{OR}=11.11$; $\mathrm{CI}=1.29-95.63)$; pre-pregnancy BMI classified as overweight or obese $(\mathrm{OR}=2.30 ; \mathrm{CI}=1.16-4.56)$ and a preference for
Caesarean section in early pregnancy $(\mathrm{OR}=3.38$; $\mathrm{CI}=1.24$ 9.17). Among women with delivery financed through the private system, having a previous caesarean section $(\mathrm{OR}=11.27$; $\mathrm{CI}=1.18-107.63)$ and the preference for this type of delivery from the beginning of pregnancy $(\mathrm{OR}=18.29$; $\mathrm{CI}=1.93-1.73$, 25) were also factors associated with current Caesarean section delivery (Table 3).

Table 3 - Final model of the independent factors associated with Caesarean section, according to type of delivery financing Maringa, PR, 2014.

\begin{tabular}{|c|c|c|c|c|c|c|}
\hline \multirow{2}{*}{ Variables } & \multicolumn{3}{|l|}{$\begin{array}{c}\text { SUS }^{\mathrm{a}} \\
\mathbf{n}(\mathbf{4 8 5})\end{array}$} & \multicolumn{2}{|c|}{$\begin{array}{l}\text { Private system } \\
\text { n (435) }\end{array}$} & \multirow[b]{2}{*}{$\boldsymbol{P}$} \\
\hline & ORaj & $\mathrm{Cl}$ & $\boldsymbol{P}$ & ORaj & $\mathrm{Cl}$ & \\
\hline \multicolumn{7}{|c|}{ Socioeconomic and demographic characteristics of mothers } \\
\hline Income per capita $\geq 1 \mathrm{SM}$ & 2.03 & $1.10-3.77$ & 0.024 & - & - & - \\
\hline \multicolumn{7}{|c|}{ Pregestational, gestational and maternal reproductive history characteristics } \\
\hline Previous C-section & 11.11 & $1.29-95.63$ & 0.028 & 11.27 & $1.18-107.63$ & 0.035 \\
\hline BMI $\geq 25$ (overweight/obesity) & 2.30 & $1.16-4.56$ & 0.018 & - & - & - \\
\hline \multicolumn{7}{|l|}{ Mother's condition during pregnancy } \\
\hline $\begin{array}{l}\text { Preference for Caesarean section early in } \\
\text { pregnancy }\end{array}$ & 3.38 & $1.24-9.17$ & 0.017 & 18.29 & $1.93-173.25$ & 0.011 \\
\hline
\end{tabular}

${ }^{\text {a }}$ Statistical adjustment for BMI $<18.5 \mathrm{~kg} / \mathrm{m}^{2}$ (underweight); hypertension during pregnancy.

${ }^{\mathrm{b}}$ Statistical adjustment for: labor in orthostatic position (standing); BMI $<18.5 \mathrm{~kg} / \mathrm{m}^{2}$ (underweight); BMI $\geq 25 \mathrm{~kg} / \mathrm{m}^{2}$ (overweight/obese).

\section{DISCUSSION}

Over time, Caesarean sections have stopped representing a method to improve perinatal outcomes and have become a consumer product, to such an extent that the rates are the lowest among the poorest women and increase as the rate at which the purchasing power of the population increases ${ }^{(7,11)}$. This may partly explain the difference in the prevalence between the public (55.5\%) and private sectors (93.8\%). Also linked to this, caesarean delivery has become a symbol of social status among Brazilian women, as well as a convenience factor for mothers and doctors who like to schedule the delivery for a certain time or day of the week ${ }^{(12)}$.

The preference for Caesarean section early in pregnancy was associated with the surgical procedure for both types of care financing (ORaj=3.38; ORaj=18.29, for the SUS and private system, respectively). Nevertheless, women assisted by the SUS have less bargaining power in choosing the mode of delivery and/or the professional who will assist them ${ }^{(13)}$, and having a preference for Caesarean section early in pregnancy (ORaj=3.38) increases the chances of this outcome. If the chances of performing a Caesarean section in the SUS are tripled among those who have a preference for this procedure, the chances are 18 times higher by using private financing (ORaj=18.29), considering that the higher the purchasing power of the clientele, the greater their bargaining power with medical professionals ${ }^{(14)}$, in addition to the bias of various professionals in the private health system for performing Caesarean sections ${ }^{(15)}$. Pregnant women assisted by private healthcare have greater decision-making power, as the organization structure of care in the private sector enables scheduling of Caesarean sections upon request, the choice of the professional/doctor, the staff, and even the health facility.
One of the reasons for choosing elective Caesarean sections, in addition to the convenience of scheduling the birth of the child, is avoiding the pain of childbirth. Many women opt for surgical birth for this reason, ignoring the possibility of receiving pain relief assistance via pharmacological and non-pharmacological methods in vaginal delivery. In Brazil, there is also an aesthetic concern associated with the myth that caesarean section will keep the anatomy and physiology of the vagina and perineum intact ${ }^{(16)}$. Another significant cultural factor is the popular belief that vaginal delivery is more risky for the unborn child than a $\mathrm{C}$-section, which is contradictory to scientific evidence ${ }^{(17-18)}$. Thus, many unwanted outcomes are usually attributed to the non-performance or late performance of caesareans. The choice by women for the type of delivery therefore has diverse influences ${ }^{(19)}$.

It is important that the established social paradigm, which has strongly influenced the "Caesarean section culture" amongst Brazilians, be reversed. Raising the awareness of mothers and professionals who provide birth assistance about the possible negative impact of surgery for the mother and the child is still the best way to reduce Caesarean section birth rates. Once the reasons why women prefer caesarean section to vaginal delivery are understood, it should be the role of medical society, managers and other health professionals to demystify these misconceptions ${ }^{(19)}$.

We must consider that only three in each ten women start pregnancy preferring a Caesarean section delivery; however, by the end of pregnancy, eight in ten opt for the $\mathrm{C}$-section ${ }^{(3)}$. This rate increases due to the influence of prenatal counseling that overestimates the risks of vaginal delivery and encourages fear and insecurity ${ }^{(20)}$. Discouraging 
vaginal delivery is strongly observed during prenatal care performed in the private system, where the follow-up is performed by only one doctor; while in the SUS in many municipalities, consultations are alternated between doctor and nurse. A population based study showed that the proportion of women who prefer a Caesarean section in the public sector did not change at the end of pregnancy, remaining close to $30 \%$. On the other hand, at the end of prenatal care in the private sector there was a significant increase in the number of women who decided for a Caesarean section, reaching $70 \%{ }^{(13)}$. This may help explain why having less than seven prenatal consultations in the private sector may constitute a protection factor for the outcome of $\mathrm{C}$-section surgery $(\mathrm{OR}=0.22)$. Studies also indicate that there is less satisfaction with Caesarean delivery, particularly among women of less favored economic classes, because in the public sector its occurrence is often associated with complications during pregnancy and delivery ${ }^{(3,11,13,20)}$.

Among the multiparous mothers, either attended by the SUS or by the private system, having a previous Caesarean section increases the chance of having another C-section by 11 times. Repeating the same surgical procedure even without clear or plausible indication is a common medical decision. Thus, the indiscriminate repetition of this procedure among multiparous mothers is a medical practice not based on evidence ${ }^{(21)}$. It has been shown that uterine scarring has little influence on the evolution of the following delivery, although it increases the risk of puerperal infections and complications in future pregnancies, such as placental abruption, bleeding disorders and neonatal morbidity ${ }^{(22)}$.

Among the users of the SUS, pregnant women undergoing Caesarean section were those who had depression $(\mathrm{OR}=4.03)$, hypertension $(\mathrm{OR}=2.10)$, diabetes $(\mathrm{OR}=4.32)$, and/or pregestational overweight/obesity $(\mathrm{OR} a \mathrm{j}=2.30)$. These are gestational risk factors that increase the likelihood of obstetric pathology, dystocia and other complications, and consequently, the indication for surgical intervention ${ }^{(23-24)}$. High gestational risk attributed to pregnant women with complications or preexisting factors is associated with a higher incidence of Caesarean section, although the intervention is not necessary in all cases ${ }^{(11,17)}$.

Despite governmental efforts in developing prevention measures for unnecessary Caesarean delivery, the actions instituted to date have been ineffective in stopping the rising trends, both in the SUS and in the private system ${ }^{(4,7)}$. The most recent Normative Resolution of the National Health Agency (ANS) (number 368/2015), ensures greater transparency in the practices of hospitals and doctors within the private healthcare and can help reduce rates ${ }^{(25)}$. Among the requirements, doctors and hospitals will now have to report the number of caesarean sections and vaginal deliveries, fill out a pregnancy record during prenatal care and use of the partograph, which records everything that happens during labor. However, in order to have real impact on the rates, perhaps measures aimed at limiting the number of procedures per health facility are required as a criteria for accreditation and financial transfers, in addition to using vaginal delivery rates as a positive indicator for quality obstetrical care ${ }^{(11)}$.

The difficulty of interfering with the increasing trend for Caesarean section rates arise from the complexity of this issue, since this is a multidimensional issue with multiple and complex determinants ${ }^{(5)}$. The maternal biological component cannot be denied, however, what most determines its occurrence in Brazil is the interaction of historically established factors, such as: the quality of vocational training; non-evidence based practice; the leading role of the obstetrician; the maternity care model (medicalization and hospitalization); the organizational format of health services; the payment per procedure; the perception of the majority of the population about the possible superiority of this type of delivery; convenience and practicality, among other cultural reasons ${ }^{(11)}$.

It is emphasized that this study has some limitations, such as the cross-sectional design, which may affect data interpretation, and the bias of the mothers' memories. However, the interviews took place immediately after delivery, minimizing the possibility of the postpartum women forgetting about gestational events.

\section{CONCLUSION}

The public and private systems reveal differences in the factors associated to Caesarean section. The high occurrence of caesarean sections in the private system (93.8\%) is mainly determined by the preference/desire of women for this type of delivery in early pregnancy $(\mathrm{OR}=18.29)$ and due to having a previous caesarean section $(\mathrm{OR}=11.27)$. Among women assisted by the SUS, there was a higher number of associated factors, including: family income per capita higher than one minimum wage $(\mathrm{OR}=2.03)$, previous caesarean section delivery $(\mathrm{OR}=11.11)$, pregestational overweight or obesity ( $\mathrm{OR}=2.30)$, and the preference/desire for Caesarean section early in pregnancy $(\mathrm{OR}=3.38)$.

Despite the occurrence of Caesarean section delivery being lower in the SUS (55.5\%) compared to the private system (93.8\%), this prevalence is still high considering the proposed incidence rates by national and international organizations. The results of this study corroborate the evidence reported in the literature, and may guide implementation of maternal and child health policies in Maringa and other municipalities with similar characteristics so that prenatal care is performed within the technical criteria recommended by WHO and the Ministry of Health in order to provide greater security and fewer complications for women and their babies.

We emphasize that investing in the education of health professionals is essential for enabling them to improve follow-up and prenatal care, in addition to vaginal delivery, and only intervening with Caesarean section where really necessary; thus ensuring good practice, humanization of care and the promotion of safe labor and births.

We point out that further randomized trials should be carried out with more numerous samples, in addition to including variables related to labor and delivery in order to consolidate the findings of this research. 
RESUMO

Objetivo: Identificar fatores associados à cesárea entre residentes de Maringá-PR, segundo a fonte de financiamento do parto. Método: Estudo transversal com dados de 920 puérperas entrevistadas entre outubro de 2013 e fevereiro de 2014. A análise de associação foi feita por regressão logística. Resultados: A taxa de cesariana foi de 55,5\% e 93,8\% no Sistema Único de Saúde (SUS) e no sistema privado, respectivamente. Associou-se à cesárea no SUS: realização de cesárea anterior $(\mathrm{OR}=8,9 ; \mathrm{IC}=4,6-16,9)$, desejo pela cesárea no início da gestação $(\mathrm{OR}=2,0 ; \mathrm{IC}=1,1-3,6)$, sobrepeso/obesidade pré-gestacional $(\mathrm{OR}=1,8 ; \mathrm{IC}=1,1-2,8)$, e renda familiar per capita maior que um salário mínimo $(\mathrm{OR}=2,1 ; \mathrm{IC}=1,3-3,4)$. No sistema privado, o desejo pela cesárea no início da gestação $(\mathrm{OR}=25,3)$ e uma cesárea anterior $(\mathrm{OR}=11,3)$ estiveram fortemente associados à sua realização. Conclusão: É necessário orientar adequadamente todas as gestantes que desejam o parto cesárea, no SUS e no sistema privado, sobre os riscos inerentes ao procedimento cirúrgico sem indicação. No setor público de saúde, devem ser foco das orientações as gestantes com parto cesárea anterior, as com renda familiar per capita maior que um salário mínimo e com sobrepeso ou obesidade, as quais têm mais chances de realizar cesárea.

\section{DESCRITORES}

Cesárea; Fatores de Risco; Saúde Materno-Infantil; Enfermagem Materno-Infantil; Financiamento da Assistência à Saúde.

\section{RESUMEN}

Objetivo: Identificar factores asociados con la cesárea entre residentes de Maringá-PR, según la fuente de financiación del parto. Método: Estudio transversal con datos de 920 puérperas entrevistadas entre octubre de 2013 y febrero de 2014. El análisis de asociación se hizo por regresión logística. Resultados: La tasa de cesáreas fue del 55,5\% y del 93,8\% en el Sistema Único de Salud (SUS) y en el sistema privado, respectivamente. Se asociaron a la cesárea en el SUS: realización de cesárea anterior $(\mathrm{OR}=8,9 ; \mathrm{IC}=4,6-16,9)$, deseo por la cesárea en el inicio de la gestación $(\mathrm{OR}=2,0 ; \mathrm{IC}=1,1-3,6)$, sobrepeso/obesidad pre gestacional $(\mathrm{OR}=1,8 ; \mathrm{IC}=1,1-2,8)$ y renta familiar per capita mayor que un sueldo mínimo $(\mathrm{OR}=2,1 ; \mathrm{IC}=1,3-3,4)$. En el sistema privado, el deseo por la cesárea en el inicio de la gestación $(\mathrm{OR}=25,3)$ y una cesárea anterior $(\mathrm{OR}=11,3)$ estuvieron fuertemente asociados con su realización. Conclusión: Es necesario orientar adecuadamente a todas las gestantes que desean el parto cesárea, en el SUS y el sistema privado, acerca de los riesgos inherente al procedimiento quirúrgico sin indicación. En el sector público de salud, deben ser foco de las orientaciones las gestantes con parto cesárea anterior, las con renta familiar per capita mayor que un sueldo mínimo y con sobrepeso u obesidad, quienes tienen más probabilidades de realizar cesárea.

\section{DESCRIPTORES}

Cesárea; Factores de Riesgo; Salud Materno-Infantil; Enfermería Maternoinfantil; Financiación de la Atención de la Salud.

\section{REFERENCES}

1. World Health Organization. Appropriate technology for birth. Lancet. 1985;2(8452):436-7.

2. Betrán AP, Ye J, Moller AB, Zhang J, Gülmezoglu AM, Torloni MR. the increasing trend in caesarean section rates: global, regional and national estimates: 1990-2014. PLoS One. 2016;11(2):e0148343.

3. Leal MC, Pereira APE, Domingues RMSM, Theme-Filha MM, Dias MAB, Nakamura PM, et al. Obstetric interventions during labor and childbirth in Brazilian low-risk women. Cad Saúde Pública. 2014;30 Suppl 1:17-32.

4. Hopkins K, Amaral EFL, Mourao ANM. The impact of payment source and hospital type on rising cesarean section rates in Brazil, 1998 to 2008. Birth. 2014;41(2):169-77.

5. Lotfi R, Tehrani FR, Dovom MR, Torkestani F, Abedini M, Sajedinead S. Development of strategies to reduce cesarean delivery rates in Iran 2012-2014: a mixed methods study. Int J Prev Med. 2014;5(12):1552-66.

6. Brasil. Ministério da Saúde. DATASUS. Informações de saúde. Estatísticas vitais. Nascidos vivos [Internet]. Brasília; 2015 [citado 2015 out. 23]. Disponível em: http://tabnet.datasus.gov.br/cgi/deftohtm.exe?sinasc/cnv/nvuf.def

7. Paris GF, Monteschio LVC, Oliveira RR, Latorre MRDO, Pelloso SM, Mathias TAF. Tendência temporal da via de parto de acordo com a fonte de financiamento. Rev Bras Ginecol Obstet. 2014;36(12):548-54.

8. Oliveira RR, Melo EC, Falavina LP, Mathias TAF. The growing trend of moderate preterm births: an ecological study in one region of Brazil. PLoS One 2015; 10(11):e0141852.

9. Nandi JK, Saha D, Mitra A, Pal S. Maternal morbidity in low risk nulliparous mother associated with cesarean delivery before labor and following induction labor. Int J Rec Sci Res. 2015;6(7):5501-04.

10. Instituto Paranaense de Desenvolvimento Econômico e Social. Caderno Estatístico Município de Maringá [Internet]. Curitiba: IPARDES; 2014 [citado 2016 fev. 16]. Disponível em: http://www.ipardes.gov.br/cadernos/MontaCadPdf1.php?Municipio=87000\&btOk=ok

11. Souza PJ, Pileggi-Castro C. On labor and childbirth: the importance of quaternary prevention. Cad Saúde Pública. $2014 ; 30$ Suppl:51-3.

12. Klimpel J, Whitson R. Birthing modernity: spatial discourses of casarean birth in São Paulo, Brazil. Gender Place Cult. 2016;23(8):1-14.

13. Domingues RMSM, Dias MAB, Nakamura MP, Torres JA, D'Orsi E, Pereira APE, et al. Process of decision-making regarding the mode of birth in Brazil: from the initial preference of women to the final mode of birth. Cad Saúde Pública. 2014;30 Suppl 1:S101-16.

14. Lino HC, Diniz SG. "You take care of the baby's clothes and I take care of the delivery": communication between professionals and patients and decisions about the mode of delivery in the private sector in São Paulo, Brazil. J Hum Growth Dev. 2015;25(1):117-24.

15. Hirsch ON. O parto "natural" e "humanizado" na visão de mulheres de camandas médias e populares no Rio de Janeiro. Civitas. 2015;15(2):229-49.

16. Muller E, Rodrigues L, Pimentel C. O tabu do parto: dilemas e interdições de um campo ainda em construção. Civitas. 2015;15(2):272-93.

17. Reis ZSN, Lage EM, Aguiar RALP, Gaspar JS, Vitral GLN, Machado EG. Associação entre risco gestacional e tipo de parto com as repercussões maternas e neonatais. Rev Bras Ginecol Obstet. 2014;36(2):65-71. 
18. Renfrew MJ, McFadden A, Bastos MH, Campbell J, Channon AA, Cheung NF, et al. Midwifery and quality care: findings from a new evidence informed framework for maternal and new born care. Lancet. 2014;384(20):1129-45.

19. Copelli FHS, Rocha L, Zampieri MFM, Gregório VRP, Custódio ZAO. Determinants of women's preference for cesarean section. Texto Contexto Enferm. 2015;24(2):336-43.

20. Weidle WG, Medeiros CRG, Grave MTQ, Dal Bosco SM. Escolha da via de parto pela mulher: autonomia ou indução? Cad Saúde Coletiva. 2014;22(1):46-53.

21. Declercq E. Is medical intervention in childbirth inevitable in Brazil? Cad Saúde Pública. 2014;30 Suppl 1:S39-40.

22. Kok N, Ruiter L, Hof M, Ravelli A, Mol BW, Pajkrt E, et al. Risk of maternal and neonatal complications in subsequent pregnancy after planned caesarean section in a first birth, compared with emergency caesarean section: a nationwide comparative cohort study. BJOG. 2014;121(2):216-23.

23. Rosendo TMSS, Roncalli AG. Prevalência e fatores associados ao Near Miss Materno: inquérito populacional em uma capital do Nordeste Brasileiro. Ciênc Saúde Coletiva. 2015;20(4):1295-304.

24. Silva JC, Amaral AR, Ferreira BS, Petry JF, Silva MR, Krelling PC. Obesidade durante a gravidez: resultados adversos da gestação e do parto. Rev Bras Ginecol Obstet. 2014;36(11):509-13.

25. Brasil. Agência Nacional de Saúde Suplementar. Resolução Normativa n. 368, de 6 de janeiro de 2015. Dispõe sobre o direito de acesso à informação das beneficiárias aos percentuais de cirurgias cesáreas e de partos normais, por operadora, por estabelecimento de saúde e por médico e sobre a utilização do partograma, do cartão da gestante e da carta de informação à gestante no âmbito da saúde suplementar [Internet]. Brasília; 2015 [citado 2015 ago. 20]. Disponível em: http://www.ahseb.com.br/wp-content/uploads/2015/05/ RN_N\%C2\%BA368.pdf 